\title{
CONTENTS VOLUME 3
}

Information science education in the United States: characteristics and curricula CAROL TENOPIR

The overlooked factor: the resource issue as the shaper of library and information school curricula DONALD DAVINSON and NORMAN ROBERTS

Education and training of library personnel in Nigeria: some challenges for the next decade BRIGGS C. NZOTTA

Outline of a methodology for training in librarianship (Short Communication) JACQUES MANIEZ

Conference Report

Book Reviews

News

Calendar of Events

Editorial

Education for research in library and information science: a basis for policy analysis in the Nordic countries

S. SCHWARZ

Artificial intelligence and expert systems research and their possible impact on information science education

HAROLD BORKO

Styles and strategies of processing information: implications for professional education NIGEL FORD

The Konstanz conception for a postgraduate programme in information science: information counselling and information management

ELISABETH VOGEL

Accreditation for all the information professions (Short Communication)

TRUDI BELLARDO

Conference Reports

Book Reviews

Book Notices 
Calendar of Events $\quad 193$

$\begin{array}{ll}\text { Editorial } & 201\end{array}$

Education for new professional roles in the information society

Sticking in the watershed for 12 years: towards restructured librarianship and information science programmes in Denmark

LEIF KAJBERG

Education for serials librarianship: what are the not so obvious basic components? MICHAEL E.D. KOENIG

Book Reviews

Book Notices

News

Calendar of Events

Library and information science education for Yugoslavia: an external view of needs and problems

WILFRED L. SAUNDERS

Library education and training for sub-professionals in developing countries E.D.T. KULARATNE

Bibliometric analysis of master theses in information sciences (Postgraduate studies in librarianship, archivistics, museology and information science, 1961-1984, Zagreb, Yugoslavia)

M. TUDMAN, M. MILAS, N. TUDOR-SILOVIC and D. BORAS

Prototype identification using a knowledge-base management system (Short Communication)

F. GIBB and B. CRONIN

Book Reviews

News

Translations of Abstracts

Calendar of Events

Author Index

Contents Volume 3 